\title{
ANALISIS FAKTOR YANG BERHUBUNGAN DENGAN USIA MENARCHE PADA SISWI KELAS VIII SMPN 2 DESA TAMBAK BAYA KECAMATAN CIBADAK KABUPATEN LEBAK TAHUN 2016
}

\author{
*Suhartini
}

\begin{abstract}
Abstrak
Menarche adalah perdarahan pertama dari uterus yang terjadi pada seorang wanita. Usia menarche dapat bervariasi pada setiap individu. Secara umum usia menarche terjadi pada usia 12-15 tahun, pada usia ini pendidikan yang ditempuh adalah SMP. Dalam 100 tahun terakhir, usia menarche telah bergeser ke usia yang lebih muda. Semmel weiss menyatakan bahwa 100 tahun yang lalu usia gadis-gadis Vienna pada waktu menarche berkisar antara 15-19 tahun. Sekarang usia gadis remaja pada waktu menarche bervariasi lebar, yaitu antara 10-16 tahun tetapi rata-rata 12,5 tahun. Hasil penjajakan awal melalui wawancara dengan pengelola program UKS di puskesmas Mandala dikemukakan bahwa belum pernah dilakukan penelitian terkait usia menarche pada siswi kelas VIII SMPN 2 desa Tambak Baya kabupaten Lebak yang termasuk ke dalam di wilayah kerja puskesmas Mandala. Penelitian ini bertujuan untuk meanganalisis faktor-faktor yang berhubungan dengan usia menarche pada siswi kelas VIII SMPN 2 desa Tambak Baya kecamatan Cibadak kabupaten Lebak tahun 2016.

Metodelogi penelitian ini menggunakan desain "crossectional" Populasi penelitian adalah seluruh siswi kelas VIII SMPN 2 desa Tambak Baya kecamatan Cibadak kabupaten Lebak berjumlah 100 orang, Sedangkan sampel penelitian sama dengan populasi. Tehnik pengambilan sampel secara purporsive sesuai dengan tujuan penelitian ditujukan kepada siswi saja. Penelitian dilaksanakan sejak bulan Mei 2016 sampai Nopember 2016. Pada penelitian ini penulis akan mengkaji lebih dalam tentang usia menarche pada wilayah pedesaan, karena dari beberapa penelitian terdahulu dilakukan diwilayah perkotaan.

Hasil Penelitian menunjukkan sebagian besar siswi menarche $>12$ tahun $(65 \%)$, Hampir seluruhnya pendidikan ibu $\leq$ SLTP (97\%), sebagian besar usia menarche ibu $>12$ tahun (82\%), sebagian usia pengenalan komunikasi HP usia > 10 tahun $(67 \%)$, sebagian besar sumber informasi menarche diperoleh melalui media non formal (77\%), hampir seluruh siswi aktifitas fisik olah raga $\leq 2 \mathrm{kl}$ per minggu (96\%), sebagian besar status gizi siswi $\leq$ Kurang (63\%). Ada hubungan bermakna antara sumber informasi dengan usia menarche (OR 0,3).Ada hubungan bermakna antara status gizi dengan usia menarche (OR 2,5). Tidak ada hubungan bermakna antara pendidikan ibu, usia menarche ibu, usia pengenalan media komunikasi HP, aktivitas olah raga dengan usia menarche.

Hasil analisis faktor risiko usia menarche diketahui ada hubungan bermakna antara sumber informasi dan status gizi dengan usia menarche. Kepada pihak sekolah disarankan untuk memberikan informasi formal melalui mata pelajaran terkait kesehatan reproduksi disekolah, mendatangkan nara sumber, serta menyebarluaskan informasi formal tentang menarche melalui buku saku, brosur, Leaflet. Kepada puskesmas diharapkan dapat menyebarluaskan informasi tentang menarche melalui penyuluhan, poster, brosur, leaflet, dan lainnya.
\end{abstract}

Daftar Pustaka; 24 ( $2001-2016)$

*) Dosen Jurusan Kebidanan Poltekkes Kemenkes Banten 


\section{Pendahuluan}

Menarche adalah perdarahan pertama dari uterus yang terjadi pada seorang wanita. Fase tibanya haid ini merupakan suatu peristiwa dimana remaja telah siap secara biologis menjalani fungsi kewanitaannya. Usia menarche dapat bervariasi pada setiap individu. Waktu mulainya haid dapat dipengaruhi beberapa faktor, misalnya genetika, status ekonomi, gizi, kegiatan fisik, dan ketinggian daerah tempat tinggal dan lainnya.

Dalam 100 tahun terakhir ini usia menarche telah bergeser ke usia yang lebih muda. Hasil riset kesehatan dasar tahun 2010 menunjukkan rata-rata usia menarche $\mathrm{di}$ Indonesia adalah 13 tahun dengan usia menarche termuda di bawah 9 tahun dan tertua 20 tahun.

Usia untuk mencapai fase terjadinya menarche dipengaruhi oleh banyak faktor antara lain faktor gizi, suku, genetik, sosial, ekonomi, dan lain-lain. Faktor gizi mempengaruhi kematangan seksual. Pada remaja yang mendapat menarche lebih dini, mereka cenderung lebih berat dan lebih tinggi pada saat menarche dibandingkan dengan yang belum menstruasi pada usia yang sama. Umumnya, remaja yang mengalami kematangan seksual lebih dini akan memiliki indeks massa tubuh yang lebih tinggi.

Peran genetik juga dianggap berpengaruh pada usia kematangan seorang wanita. Ong et al menyatakan umur menarche ibu dapat mempengaruhi kecepatan pertumbuhan badan anak sehingga mempengaruhi waktu menarchenya. Faktor lain yang dianggap berhubungan yaitu faktor sosial ekonomi. Keadaan sosial ekonomi berhubungan dengan kemampuan daya beli keluarga, baik itu daya beli makanan maupun dalam hal pemenuhan kebutuhan material seorang gadis remaja.

Melihat begitu kompleksnya permasalahan yang mempengaruhi usia menarche seseorang, dan diketahui bahwa secara umum usia menarche terjadi pada usia 12-15 tahun. Pada usia ini jenjang pendidikan yang ditempuh adalah SMP. Usia menarche awal umumnya terjadi pada usia 12 tahun atau setara dengan SMP kelas VIII. Oleh karena itu penulis tertarik untuk meneliti tentang faktor apa saja yang mempengaruhi usia menarche pada siswi SMPN2 desa Tambak Baya kecamatan Cibadak kabupaten Lebak. Lokasi Penelitian ini berada di wilayah pedesaaan desa Tambak Baya dan termasuk ke dalam wilayah kerja Puskesmas Mandala dimana puskesmas ini aktif menjalankan program UKS ke SMPN 2 ini.

\section{Metode Penelitian}

Desain penelitian ini adalah Desain Cross sectional. Lokasi penelitian di SMPN 2 desa Tambak Baya kecamatan Cibadak kabupaten Lebak. Waktu penelitian dilaksanakan sejak bulan Mei sampai dengan November 2016. Objek penelitian 
adalah seluruh remaja putri siswi SMPN 2 kelas VII di Kecamatan Cibadak sebanyak 107 orang (data program UKS Puskesmas Mandala tahun 2015). Sampel penelitian ini sama dengan populasi. Tehnik pengambilan sampel secara Purposive didasarkan pada pertimbangan tertentu yaitu di spesifikasikan hanya pada remaja puti (siswi) SMPN.Kelas VIII SMPN 2 desa Tambak Baya kecamatan Cibadak kabupaten Lebak tahun 2016.

\section{Hasil}

1. Analisis Univariat

\section{Tabel 1}

Distribusi Frekuensi usia menarche Pada siswi kelas VIII SMPN2 Desa Tambak Baya Kecamatan Cibadak Kabupaten Lebak tahun 2016

\begin{tabular}{l|c|c}
\hline Usia menarche & Frekuensi & $\%$ \\
\hline$\leq 12$ tahun & 35 & 35 \\
$>12$ tahun & 65 & 65 \\
\hline Jumlah & 100 & 100 \\
\hline
\end{tabular}

Pada tabel 1 terlihat bahwa sebagian besar siswi kelas VIII SMPN2 desa Tambak Baya kecamatan Cibadak mengalami menarche > dari 12 tahun $(65 \%)$

Tabel 2

Distribusi tingkat pendidikan Ibu Pada siswi kelas VIII SMPN2 Desa Tambak Baya Kecamatan Cibadak Kabupaten Lebak tahun 2016

\begin{tabular}{l|c|c}
\hline Pendidikan & Frekuensi & $\%$ \\
\hline$>$ SLTP & 3 & 3 \\
$\leq$ SLTP & 97 & 97 \\
\hline Jumlah & 100 & 100 \\
\hline
\end{tabular}

Pada tabel 2 terlihat bahwa hampir seluruhnya ibu berpendidikan $\leq$ SLTP (97\%).

Tabel 3

Distribusi Frekuensi usia menarche Ibu Pada siswi kelas VIII SMPN2 Desa Bojongleles Kecamatan Cibadak Kabupaten Lebak tahun 2016

\begin{tabular}{l|c|c}
\hline Usia menarche Ibu & Frekuensi & $\%$ \\
\hline$\leq 12$ tahun & 18 & 18 \\
$>12$ tahun & 82 & 82 \\
\hline Jumlah & 100 & 100 \\
\hline
\end{tabular}

Pada tabel 3 terlihat sebagian besar usia menarche ibu diatas 12 tahun (82\%)

Tabel 4

Distribusi Frekuensi Usia pengenalan media komunikasi Pada siswi kelas VIII

SMPN2 Ds Bojongleles Kecamatan Cibadak Kabupaten Lebak tahun 2016

\begin{tabular}{l|c|c}
\hline Usia Pengenalan HP & Frekuensi & $\%$ \\
\hline$\leq 10$ tahun & 33 & 33 \\
$>10$ tahun & 67 & 67 \\
\hline Jumlah & 100 & 100 \\
\hline
\end{tabular}

Pada tabel 4 terlihat bahwa lebih dari sebagian usia pengenalan media komunikasi HP pada siswi SMPN2 desa Tambak Baya kecamatan Cibadak >10 tahun $(67 \%)$

Tabel 5

Distribusi Frekuensi sumber informasi Pada siswi kelas VIII SMPN2 Ds Bojongleles Kecamatan Cibadak Kabupaten Lebak tahun 2016

\begin{tabular}{l|c|c}
\hline Sumber Informasi & Jumlah & $\%$ \\
\hline Formal & 23 & 23 \\
Non formal & 77 & 77 \\
\hline Jumlah & 100 & 100 \\
\hline
\end{tabular}


Pada tabel 5 terlihat bahwa sebagian besar sumber informasi menarche diperoleh melalui media informal (77\%)

Tabel 6

Distribusi Frekuensi Aktivitas fisik Pada siswi kelas VIII SMPN2 Desa Tambak Baya Kecamatan Cibadak Kabupaten Lebak tahun 2016

\begin{tabular}{l|c|c}
\hline Aktifitas Fisik & Frekuensi & $\%$ \\
\hline$>2 \mathrm{kali} /$ minggu & 4 & 4 \\
$\leq 2 \mathrm{kali} /$ minggu & 96 & 96 \\
\hline Jumlah & 100 & 100 \\
\hline
\end{tabular}

Pada tabel 6 terlihat bahwa hampir seluruh siswi kelas VIII SMPN2 Tambak Baya kecamatan Cibadak kabupaten Lebak tahun 2016 melakukan aktifitas fisik olah raga $\leq 2$ kali sebesar (96\%)

Tabel 7

Distribusi Frekuensi Status Gizi Pada siswi kelas VIII SMPN2 Desa Tambak Baya Kecamatan Cibadak Kabupaten Lebak tahun 2016

\begin{tabular}{l|c|c}
\hline Status Gizi & Frekuensi & $\%$ \\
\hline$\geq$ Normal & 37 & 37 \\
$<$ Kurang & 63 & 63 \\
\hline Jumlah & 100 & 100 \\
\hline
\end{tabular}

Pada tabel 7 terlihat bahwa distribusi frekuensi status gizi pada siswi kelas VIII SMPN2 desa Tambak Baya kecamatan Cibadak dengan Gizi Kurang (63\%)

\section{Analisis Bivariat}

a. Hubungan Pendidikan Ibu dengan usia menarche pada siswi SMPN 2 desa Tambak Baya kecamatan Cibadak tahun 2016
Hasil analisis data bivariat menunjukkan proporsi usia menarche $\leq 12$ tahun lebih banyak ditemukan pada ibu yang berpendidikan $\leq \operatorname{SLTP}(35,1 \%)$ dibandingkan ibu dengan pendidikan $>\operatorname{SLTP}(33,3 \%)$.

Hasil analisis lebih lanjut diperoleh nilai $\mathrm{P}$ value $>\alpha$ (1.0) artinya tidak ada hubungan yang bermakna antara pendidikan ibu dengan usia menarche

b. Hubungan usia menarche Ibu dengan usia menarche pada siswi SMPN 2 desa Tambak Baya kecamatan Cibadak tahun 2016.

Hasil Penelitian menunjukkan bahwa proporsi usia menarche cepat $(\leq 12$ tahun), lebih banyak ditemukan pada ibu yang mengalami menarche $\leq 12$ tahun $(44,4 \%)$ dibandingkan ibu yang mengalami menarche > 12 tahun (32,9\%). Hasil analisis lebih lanjut diperoleh $\mathrm{P}$ value $>\alpha$ $(0,5)$ artinya tidak ada hubungan yang bermakna antara usia menarche ibu dengan kejadian menarche lebih awal $(\leq 12$ tahun)

c. Hubungan usia pengenalan media komunikasi (HP) dengan usia menarche pada siswi SMPN 2 desa Tambak Baya kecamatan Cibadak tahun 2016

Hasil analisis menunjukkan proporsi usia menarche cepat ( $\leq 12$ tahun), lebih banyak ditemukan pada siswi yang 
menggunakan media komunikasi HP > 10 tahun $(37,3 \%)$ dibandingkan dengan siswi yang mengenal media komunikasi pada usia $\leq 10$ tahun $(30,3 \%)$. Hasil analisis lebih lanjut diperoleh $\mathrm{P}$ value $>\alpha \quad(0,6)$ artinya tidak ada hubungan yang bermakna antara penggunaan media komunikasi (HP) dengan kejadian menarche cepat

\section{d. Hubungan Sumber Informasi dengan} usia menarche pada siswi SMPN 2 desa

Tambak Baya kecamatan Cibadak tahun 2016

Hasil analisis Bivariat menunjukkan proporsi usia menarche cepat ( $\leq 12$ tahun), lebih banyak ditemukan pada siswi yang memperoleh informasi secara Non formal $(41,6 \%)$ dibandingkan dengan siswi yang menerima informasi formal (13\%). Hasil analisis lebih lanjut diperoleh diperoleh $\mathrm{P}$ value $<\alpha(0,0)$ artinya ada hubungan yang bermakna antara sumber informasi dengan kejadian menarche cepat Hasil analisis lanjut diperoleh nilai OR 0,3 artinya pendidikan Non formal hanya dapat mencegah $3 \%$ kejadian menarche lebih cepat dibandingkan dengan pendidikan formal.

e. Hubungan Aktifitas Fisik (Olah raga) dengan kejadian menarche pada siswi SMPN 2 desa Tambak Baya kecamatan Cibadak tahun 2016
Hasil

analisis

bivariat menggambarkan proporsi usia menarche cepat ( $<12$ tahun), lebih banyak ditemukan pada siswi yang melakukan aktivitas fisik olah raga $\leq 2$ kali per minggu $(36,5 \%)$ dibandingkan dengan siswi yang melakukan aktifitas fisik $\geq 2$ kali per minggu $(0 \%)$ Hasil analisis lebih lanjut diperoleh $\mathrm{P}$ value $>\alpha \quad(0,2)$ artinya tidak ada hubungan yang bermakna antara aktifitas fisik dengan kejadian menarche cepat.

f. Hubungan Status Gizi dengan kejadian menarche pada siswi SMPN 2 desa Tambak Baya kecamatan Cibadak tahun 2016

Hasil analisis menunjukkan bahwa proporsi usia menarche cepat ( $\leq 12$ tahun), lebih banyak ditemukan pada siswi dengan status gizi $\geq$ Normal $(56,8)$ dibandingkan dengan siswi yang status gizi $<\operatorname{kurang}(22,2 \%)$ Hasil analisis lebih lanjut diperoleh $\mathrm{P}$ value $<\alpha(0,00)$ artinya ada hubungan yang bermakna antara status gizi dengan kejadian menarche cepat. Analisis lanjut ditunjukkan dengan nilai OR sebesar 2,5 artinya siswi dengan status gizi normal memiliki risiko sebesar 3 kali untuk menarche lebih cepat dibanding status gizi Kurang 


\section{Pembahasan}

1. Hubungan pendidikan Ibu dengan usia menarche pada siswi SMPN 2 Desa

Tambak Baya kecamatan Cibadak tahun 2016

$$
\text { Pendidikan ibu sangat }
$$
mempengaruhi komunikasi antara ibu dan anak. Penelitian oleh Fox dan inazu terhadap terhadap 449 pasangan ibu-anak remaja putri menunjukkan hasil bahwa perlunya pendidikan seks bagi remaja khususnya yang dilakukan oleh orang tua. Penelitian yang dilakukan menunjuklan bahwa makin sering percakapan tentang seks antara ibu dan anak maka tingkah laku seksual anakpun semakin bertanggung jawab (Wirawan.S).

Komunikasi ibu-anak merupakan proses pengiriman dan penerimaan pesan antara ibu dan anak yang berlangsung secara tatap muka dan dua arah (interpersonal) dan disertai adanya niat atau intense dari kedua belah pihak, dimana keduanya berperan sebagai pembicara dan pendengar secara bergantian sehingga menimbulkan efek tertentu berupa respon dan umpan balik segera (feedbac). Hasil yang tidak bermakna ini dimungkinkan karena proporsi ibu yang berpendidikan SLTP keatas sangat sedikit yaitu sebanyak (3\%) bila dibandingkan dengan ibu yang berpendidikan SD (97\%)
Setiap wanita remaja yang mengalami transisi kedewasaan atau mulai menampakkan tanda - tanda pubertas, terutama menarche akan mengalami kecemasan. Penjelasan dari orang tua tentang menarche dan permasalahannya akan mengurangi kecemasan remajaputri ketika menarche datang. Disinilah orang tua sangat dibutuhkan terutama pada ibu. Dapat dibayangkan apabila Ibu tersebut berpendidikan rendah dan tidak mempunyai informasi yang cukup tentang menarche.

2. Hubungan usia menarche Ibu dengan usia menarche pada siswi SMPN 2 desa Tambak Baya kecamatan Cibadak tahun 2016;

Usia menarche ibu berkaitan dengan usia menarche anak tidak hanya karena pengaruh genetik tapi juga berkaitan dengan lingkungan keluarga. Hasil analisis lebih lanjut tentang hubungan antara usia menarche ibu dengan menarche responden di peroleh proporsi usia menarche cepat lebih banyak ditemukan pada ibu yang berusia $\leq 12$ tahun $(44,4 \%)$ dibandingkan ibu > 12 tahun (32,9\%). Hasil analisis lebih lanjut diperoleh $\mathrm{P}$ value $>\alpha \quad(0,5)$ artinya tidak ada hubungan yang bermakna antara usia menarche ibu dengan kejadian menarche cepat. Hasil penelitian ini sejalan dengan hasil penelitian Amelia Demina Karis bahwa Berdasarkan uji statistik chi- 
square didapatkan nilai $p=0,459(p>0,05)$ maka secara statistik tidak terdapat hubungan antara usia menarche responden dengan usia menarche ibu.

3. Hubungan usia pengenalan media komunikasi (HP) dengan usia menarche pada siswi SMPN 2 desa Tambak Bayah Kecamatan Cibadak tahun 2016

Terbukanya akses informasi memungkinkan setiap orang untuk mengakses berbagai macam informasi termasuk yang menyajikan adegan seksual secara implisit. Media yang ada, baik media elektronik maupun media cetak contohnya, kerap kali menyuguhkan sajian-sajian yang terlalu dini ataupun tidak layak dikonsumsi bagi anak-anak dan remaja. Hal lain yang menjadi tren saat ini adalah keberadaan jejaring sosial seperti Facebook atau Friendster yang dikenal luas di masyarakat. Jejaring sosial tersebutselain membawa manfaat positif juga membawa dampak negatif bagi remaja. Manfaat positifnya selain mempererat tali silaturahmi juga bisa mendapatkan informasi terbaru dari status orang lain sedangkan dampak negatifnya yait dapat mengganggu privasi, membuat ketagihan sehingga dapat mengganggu waktu untuk belajar dan dapat mempengaruhi para remaja untuk melakukan seks bebas. Sajian media sosial terlalu dini ini, dikhawatirkan berdampak terhadap perkembangan seksual dini pula sebagaimana hasil penelitian Indriyastuti (2011) ada hubungan antara riwayat menonton audio visual dengan usia menarche. Namun dari hasil penelitian menunjukkan bahwa usia pengenalan media komunikasi (HP) pada siswi SMPN2 desa Tambak Baya kecamatan Cibadak > 10 tahun (67\%) Hasil analisis lanjut diketahui proporsi usia menarche cepat ( $\leq 12$ tahun), tidak jauh berbeda pada siswi yang mengenal media komunikasi pada usia $>10$ tahun $(37,3 \%)$ dibandingkan dengan siswi yang berusia $\leq 10$ tahun (30,3\%), namun setelah diuji secara statistic diperoleh P. value $>\alpha(0,6)$ artinya tidak ada hubungan yang bermakna antara penggunaan media komunikasi (HP) dengan kejadian menarche dini.

\section{Hubungan Sumber Informasi dengan usia menarche pada siswi SMPN 2 desa Tambak Baya kecamatan Cibadak tahun 2016}

Estrogen dengan konsentrasi rendah sudah mampu merangsang pertumbuhan payudara karena organ ini mempunyai reseptor untuk estrogen, khususnyapada glandulanya. Estrogen juga menimbulkan kematangan organ-organ reproduksi dan perubahan organ-organ seks sekunder, diantaranya : distribusi rambut, deposit jaringan lemak, dan akhirnya 
perkembangan endometrium di dalam uterus. Rangsangan estrogen yang cukup lama terhada endometrium akhirnyaa perdarahan lucut pertama yang disebut menarche (Guyton \& Hall, 2007), dalam Aryani Wulansari Niken (2012)

\section{Hubungan Aktifitas Fisik (Olah raga)} dengan kejadian menarche pada siswi SMPN 2 desa Tambak Baya kecamatan Cibadak tahun 2016.

Hasil penelitian menunjukkan tidak ada hubungan antara aktifitas fisik dengan kejadian menarche. Hal ini sejalan dengan hasil penelitian Aryati Dian Faktor yang berhubungan dengan usia menarche pada remaja SD,SLTP di kota Bandung tahun 2007 diperoleh hasil uji statistik dengan nilai $\mathrm{p}$ value 0,532 yang berarti pada alpha $=5 \%$ tidak ada perbedaan usia menarche antara responden dengan kegiatan fisik tidak aktif dengan kegiatan fisik aktif. Hasil penelitian ini juga sejalan dengan hasil penelitian Fidrin dkk, Berdasarkan hasil analisis statistik dengan menggunakan uji chi square diperoleh nilai $p=0,65$, hal ini berarti tidak ada hubungan yang bermakna antara aktivitas fisik dengan usia menarche Menurut peneliti tidak bermaknanya aktivitas fisik ini karena responden hanya melakukan aktifitas pada kegiatan fisik seperti olahraga di sekolah dengan frekuensi rata-rata 1 kali per minggu dan aktivitas ini tidak dilakukan secara rutin pada saat responden berada dirumah.

6. Hubungan Status Gizi dengan kejadian menarche pada siswi SMPN 2 desa Tambak Baya kecamatan Cibadak tahun 2016

Gizi mempengaruhi kematangan seksual pada remaja yang mendapat menarche lebih dini. Pada umumnya, mereka yang menjadi matang lebih dini akan memiliki Indeks Masa Tubuh (IMT) yang lebih tinggi dan mereka yang matang terlambat memiliki IMT lebih kecil pada usia yang sama.

\section{Simpulan}

Dari hasil penelitian tentang Analisis faktor yang berhubungan dengan usia menarche pada siswi kelas VIII SMPN2 Desa Tambak Baya Kecamatan Cibadak Kabupaten Lebak tahun dapat disimpulkan sebagai berikut;

1. Sebagaian besar siswi mengalami menarche pada usia > 12 tahun (65\%)

2. Hampir seluruhnya ibu berpendidikan SD $(97 \%)$

3. Sebagaian besar usia menarche Ibu pada usia > 12 tahun $(82 \%)$

4. Sebagaian besar usia pengenalan media komunikasi HP pada usia > 10 tahun $(67 \%)$ 
5. Sebagian besar sumber informasi menarche diperoleh secara nonformal $(77 \%)$

6. Hampir seluruh aktifitas fisik olah raga siswi $\leq 2$ kali per minggu (96\%)

7. Sebagian besar status gizi siswi <Kurang $(63 \%)$

8.Tidak ditemukan hubungan yang bermakna antara pendidikan ibu, usia menarche ibu, pengenalan media komunikasi, aktifitas fisik olah raga dengan usia menarche pada siswi kelas VIII SMPN 2 desa Tambak Baya kecamatan Cibadak kabupaten Lebak tahun 2016

9. Ada hubungan bermakna antara sumber informasi dan status gizi dengan usia menarche pada siswi kelas VIII SMPN2 Tambak Baya kecamatan Cibadak kabupaten Lebak tahun 2016

\section{Daftar Pustaka}

Alimul Hayat A.Aziz, Metode Penelitian Kebidanan dan tehnik analisa data, Salemba medika Jakarta, 2011.

Amalia Demina Karis, Faktor-faktor yang berhubungan dengan usia menarche pada remaja putri SMPN 155 Jakarta 2011

Aryati Dian, Faktor yang berhubungan dengan nusia menarche pada remaja SD,SLTP di kota Bandung tahun 2007, Jurnal Kesehatan Masyarakat Nasional Vol 2 juni 2008
Aryani Wulansari Niken,dkk Hubungan Komsumsi Junkfood dengan media informasi terhadap menarche dini, pada siswi Sekolah Dasar di Surakarta tahun 2012

Dahro Ahmad, Psikologi Kebidanan, Analisis Perilaku wanita untuk kesehatan, Salaemba Medika, tahun 2011

Damayanti D. Faktor-faktor yang berhubungan dengan umur menarche mahasiswi baru $\mathrm{S} 1$ reguler Universitas Indonesia Tahun ajaran 2000/2001 [tesis]. Depok: Universitas indonesia; 2001.

Danim Darwis Sudarwan.SKP, Metode Penelitian Kebidanan, prosedur, kebijakan dan etik, ECG, Jakarta 2003

Fidrin,Dkk. Faktor yang berhubungan dengan usia menarche pada siswi SMP Negeri 3 Sumbul tahun 2014

Indriyastuti Hastin Ika dkk. Hubungan Riwayat menonton audio visual dengan usia menarche pada siswi SLTP kecamatan Kebumen, Jurnal ilmiah keperawatan volume 11 No 2 Juni 2015)

Khairani Maya, dkk, Hubungan antara komunikasi ibu dan anak dengan kesiapan menghadapi menstruasi pertama (menarche), pada siswi SMP Banda Aceh, Jurnal Psikologi UNDIP vol 10. No 2 hal 134-143 , Muha Medika, Yogyakarta Oktober 2011

Llewellyn-Jones, Derek, Dasar-dasar Obstetri Ginekologi ( Fundamental of obstetrics and Gynokology, adisi 6 . Jakarta 2001 
Manuaba Ayu Chandranita, Memahami kesehatan reproduksi wanita, ECG 2009

Notoatmodjo Soekidjo, Metodelogi Penelitian kesehatan, Rineka Cipta Jakarta tahun 2010

Putri AK. Hubungan antara status gizi, status menarche ibu, media massa, aktivitas olahraga dengan status menarche siswi di SMP Islam AlAzhar Rawamangun, Jakarta Timur tahun 2009 [skripsi]. Depok: Universitas indonesia; 2009

Pinem Saroha, Kesehatan eproduksi dan Kontrasespsi, trans info media Jakarta tahun 2009

Pujiningtiyas, Lia Ratnasari, Artikel Publikasi ilmiah, Hubungan penggunaan media sosial dengan perilaku seks siswa SMP di Surakarta, tahun 2014

Rizvya,dkk Analisis factor yang berhubungan dengan usia menarche pada siswi SMP swasta harapan 1 dan 2 Medan 2014

Stevany sarah dkk,. Hubungan IMT dengan usia menarche pada siswi SD, SMP di kota Manado, Bagian OBGYN Universitas Sam Ratulangi, tahun 2012

UNFPA, BKKBN, Keluarga Berencana, Kesehatan reproduksi, Gender dan Pembangunan Kependudukan, edisi revisi, Jakarta 2006

Yusuf, Syamsu LN, MPd, Psikologi Perkembangan anak dan remaja, PT Remaja Rosdakarya Bandung tahun 2005 www/http Wol.Jw.org/id/r25/Ip/in/102006 164.Menyiapkan putri anda menghadapi menarche

http://www.dokter .id Tanda terjadinya menstruasi pada wanita, 20 April 2016

www.smallcrab.com/seksualitas, Seksualitas. 20 April 2016

Wiknjosastro Hanifa, Ilmu Kebidanan, edisi dua cetakan ketujuh, PT Bina Pustaka Sarwono Prawiroharjo, Jakarta 2009 